\title{
JNPH
}

Volume 6 No. 2 (Oktober 2018)

(C) The Author(s) 2018

\section{EFEKTIVITAS KONSENTRASI KLORIN TERHADAP DAYA TETAS TELUR NYAMUK AEDES AEGYPTI}

\section{EFFECTIVENESS OF CHLORINE CONCENTRATION TO EFFECTIVENESS OF MOSQUITO EGGS AEDES AEGYPTI}

\author{
HAIDINA ALI, ULLYA RAHMAWATI \\ DOSEN JURUSAN KESEHATAN LINGKUNGAN POLTEKKES \\ KEMENKES BENGKULU \\ E-mail : alimanafh@gmail.com
}

\begin{abstract}
ABSTRAK
Latar Belakang:Kandungan zat kimia dalam air juga mempengaruhi daya tetas telur Aedes aegypti, salah satunya ialah kaporit. Sebelumnya telah dilakukan penelitian bahwa kaporit pada media air dapat mengganggu proses perkembangan dan penetasan telur karena terdapat klorin dalam kaporit yang mampu mengoksidasi (membakar) telur nyamuk Aedes aegyptidengan merusak protein yang terdapat dalam telur nyamuk Aedes aegypti.Tujuan dari penelitian ini adalah untuk mengetahui Perbedaan konsentrasi klorin terhadap daya tetas telur nyamuk Aedesaegypti. Metode :Jenis penelitian ini berupa penelitiandengan metode Eksperimen. Rancangan Penelitian ini adalah post test with control only design. Analisis yang digunakan adalah uji One Way Anova dan uji Benferonny. Hasil Penelitian : Dari analisis Univariat menunjukkan bahwa kelompok control $(0 \mathrm{mg} / \mathrm{l})$ memiliki jumlah kematian terbanyak dengan persentase telur nyamuk Aedes aegypti yang tidak menetas 7\% dengan rata-rata 1,4, kelompok konsentrasi $10 \mathrm{mg} / \mathrm{l}$ dengan persentase telur nyamuk Aedes aegypti yang tidak menetas $68 \%$ dengan rata-rata 13,6, kelompok konsentrasi13 mg/ldengan persentase telur nyamuk Aedes aegypti yang tidak menetas 77 \%dengan rata-rata 15,4, kelompok konsentrasi $16 \mathrm{mg} / 1 \mathrm{dengan}$ presentasi telur nyamuk Aedes aegypti yang tidak menetas $87 \%$ dengan rata-rata 17,4, sedangkan pada kelompok konsentrasi klorin $18 \mathrm{mg} / \mathrm{l}$ dengan persentase telur nyamuk Aedes aegypti yang tidak menetas 98\% dengan rata-rata 19,6. Saran :Diharapkan penelitian ini dapat memberikan informasi bagi masyarakat tentang salah satu solusi pencegahan penyakit demam berdarah dengue (DBD) dengan menggunakan konsentrasi klorin yang mampu menghambat daya tetas telur nyamuk Aedes aegypti.
\end{abstract}

Kata Kunci : Konsentrasi klorin, telur nyamuk Aedes Aegypti,.

\begin{abstract}
Background: Chemical content in water also affects the hatchability of Aedes aegypti eggs, one of which is chlorine. Previous research has been done that chlorine in water media can disrupt the process of development and hatching of eggs because there is chlorine in chlorine that is able to oxidize (egg) Aedes aegypti mosquitoes by destroying the protein contained in Aedes aegypti mosquito eggs. The purpose of this research is to know the difference of chlorine concentration to hatchability of Aedes aegypti mosquito egg. Method: This research type is
\end{abstract}


research with experiment method. The design of this study is post test with control only design. The analysis used is One Way Anova test and Benferonny test. Results: From the Univariate analysis showed that the control group $(0 \mathrm{mg} / 1)$ had the highest number of deaths with the percentage of Aedes aegypti mosquito eggs that did not hatch $7 \%$ with an average of 1.4 , the concentration group of $10 \mathrm{mg} / 1$ with the percentage of Aedes mosquito egg aegypti that did not hatch $68 \%$ with mean 13,6 , group concentration $13 \mathrm{mg} / 1$ with percentage of Aedes aegypti mosquito egg which did not hatch $77 \%$ with average 15,4 , group concentration $16 \mathrm{mg} / 1$ with presentation of Aedes mosquito egg aegypti that did not hatch $87 \%$ with an average of 17,4 , while in group of chlorine concentration $18 \mathrm{mg} / 1$ with percentage of Aedes aegypti mosquitoes which did not hatch $98 \%$ with mean of 19,6 . Suggestion: It is expected that this research can provide information for the community about one of dengue dengue fever prevention solution (DBD) by using chlorine concentration which able to inhibit the hatchability of Aedes aegypti mosquito egg.

\section{Keywords: Chlorine concentration, Aedes Aegypti mosquito egg •}

\section{PENDAHULUAN}

Penyakit Demam Berdarah Dengue atau yang lebih sering kita kenal DBD merupakan salah satu masalah kesehatan masyarakat di Indonesia yang jumlah penderitanya cenderung meningkat dan penyebarannya semakin luas. DBD memiliki perjalanan yang sangat cepat dan sering menjadi fatal karena banyak pasien yang meninggal akibat penanganannya yang terlambat (Widiyono, 2008).

Tempat potensial untuk perindukan nyamuk Aedes aegyptiadalah natural container(tempat perindukan alami) seperti lubang pohon, batok kelapa, atau lubang breedingdi batu dan artificial container (tempat perindukan buatan) seperti bak mandi, ember, dispenser, kulkas, ban bekas, pot/vas bunga, kaleng bekas, botol plastik, (Trpis dkk, 1971 dan Ditjen P2PL, 2014).

Kandungan zat kimia dalam air juga mempengaruhi daya tetas telur Aedes aegypti, salah satunya ialah kaporit. Selain kaporit mudah di dapat, harganya juga terjangkau dan sebelumnya telah dilakukan penelitian bahwa kaporit pada media air dapat mengganggu proses perkembangan dan penetasan telur karena terdapat klorin dalam kaporit yang mampu mengoksidasi (membakar) telur nyamuk Aedes aegyptidengan merusak protein yang terdapat dalam telur nyamuk Aedes aegypti ( Hindiyah Effendi, 2008).
Pengendalian nyamuk dewasa dan larva belum menunjukkan keberhasilanya secara signifikan hal ini dapat di lihat dari kejadian DBD di Indonesia. Berdasarkan penelitian yang telah dilakukan oleh Bina Ikawati, dkk, tahun 2015. Hasil penelitian menunjukkan pada konsentrasi kaporit 10 $\mathrm{mg} / \mathrm{l}$ daya tetas telur nyamuk aedes aegypti hanya $48,75 \%$. Oleh karena itu peniliti ingin melanjutkan penelitian dengan cara meningkatkan konsentrasi klorin untuk mendapatkan daya tetas telur nyamuk yang minimal.

Berdasarkan uraian diatas maka penyusun tertarik untuk melakukan penelitian berjudul "Perbandingan Konsentrasi klorin terhadap daya tetas telur nyamuk Aedesaegypti".

Tujuan penelitian ini adalah Diketahui Perbedaan Konsentrasi klorin terhadap daya tetas telur nyamuk Aedesaegypti.

\section{METODE PENELITIAN}

Jenis penelitian ini berupa penelitiandengan metode Eksperimen. Rancangan Penelitian ini adalah post test with control only design. .

\section{HASIL PENELITIAN}

\section{Analisis Univariat}

Berdasarkan hasil penelitian yang 
dilakukan di Laboratorium Terpadu Poltekkes Kemenkes Bengkulu, jumlah telur nyamuk Aedes aegypti yang mati pada konsentrasi klorin $10 \mathrm{mg} / \mathrm{l} ; 13 \mathrm{mg} / \mathrm{l} ; 16 \mathrm{mg} / \mathrm{l}$; $18 \mathrm{mg} / \mathrm{l}$ di lakukan sebanyak 5 kali pengulangan dan juga dilakukan pemeriksaan PH dan sisaklor. Maka diperoleh hasil jumlah telur nyamuk Aedes aegyptiyang mati pada masing-masing konsentrasi klorin, seperti pada tabel berikut:

Tabel 1 Distribusi frekuensi jumlah telur nyamuk Aedes aegypti yang tidakmenetas pada konsentrasi klorin $10 \mathrm{mg} / \mathrm{l} ; 13 \mathrm{mg} / \mathrm{l}$; 16 mg/l; 18 mg/l

\begin{tabular}{lccc}
\hline No & KonsentrasiKlorin & $\begin{array}{c}\text { Rata-rata } \\
\text { telurnyamuk } \\
\text { yang } \\
\text { tidakmenetas }\end{array}$ & \% \\
\hline 1 & Control & 1,4 & $7 \%$ \\
\hline 2 & $10 \mathrm{mg} / 1$ & 13,6 & $68 \%$ \\
\hline 3 & $13 \mathrm{mg} / 1$ & 15,4 & $77 \%$ \\
\hline 4 & $16 \mathrm{mg} / 1$ & 17,4 & $87 \%$ \\
\hline 5 & $18 \mathrm{mg} / 1$ & 19,6 & $98 \%$ \\
\hline
\end{tabular}

Tabel 1 menunjukkan bahwa dari kontroldan 4 perlakuandengan total jumlah telurnyamuk Aedes aegypti sebanyak 500 butir setelah dilakukan penelitian kematian telur nyamuk Aedes aegypti tertinggi (98\%) terjadi pada perlakuan konsentrasi klorin 18 $\mathrm{mg} / \mathrm{l}$.

\section{Analisis Bivariat}

Berdasarkan tes normalitas didapat hasil Kolmogorov-Smirnov Z $0.138>0,05$ data terdistribusi normal, dilanjutkan dengan uji parametrik One way Anova. Hasil dari Anova nilai signifikansi Sig $=0,000$ berarti mempunyai data yang berbeda signifikan. Dilanjutkan dengan uji posh hoc yaitu untuk membandingkan setiap kelompok uji dengan kelompok lainnya.

Tabel 2 Hasil Uji One Way Anova Pengaruh Jumlah telur nyamuk Aedes aegypti yang mati pada konsentrasi klorin Berbagai
Variasi dosis.

\begin{tabular}{|c|c|c|c|}
\hline & Mean SD & $95 \%$ CI & $\underset{\text { Value }}{\rho}$ \\
\hline Kontrol & $1,40,548$ & $\begin{array}{l}, 72- \\
2, \rho 08\end{array}$ & \multirow[t]{6}{*}{.000} \\
\hline $\begin{array}{c}\text { Konsentrasi } \\
10 \mathrm{mg} / \mathrm{l}\end{array}$ & $13,601,817$ & $11,34-15,86$ & \\
\hline $\begin{array}{c}\text { Konsentrasi } \\
13 \mathrm{mg} / \mathrm{l}\end{array}$ & $15,401,517$ & $13,52-17,28$ & \\
\hline $\begin{array}{c}\text { Konsentrasi } \\
16 \mathrm{mg} / \mathrm{l}\end{array}$ & $17,401,140$ & $15,98-18,82$ & \\
\hline $\begin{array}{c}\text { Konsentrasi } \\
18 \mathrm{mg} / \mathrm{l}\end{array}$ & $19,60,548$ & $18,92-20,28$ & \\
\hline Total & $13,486,590$ & $10,76-16,20$ & \\
\hline
\end{tabular}

Tabel 2 hasil uji One Way Anova didapat nilai $\mathrm{Sig}=0,000<0,05$ dapat diartikan bahwa secara statistik Ho ditolak dan Ha diterima, disimpulkan bahwa ada perbedaan jumlah telur nyamuk Aedes Aegypti yang mati pada penambahan konsentrasi klorin $10 \mathrm{mg} / 1,13 \mathrm{mg} / 1,16 \mathrm{mg} / \mathrm{l}$, dan $18 \mathrm{mg} / \mathrm{l}$.

Selanjutnya untuk mengetahui selisih kematian telur nyamuk Aedes Aegypti antar kelompok konsentrasi korin dengan berbagai variasi dosis serta kontrol, dilakukan uji bonferroni. Hasil uji bonferroni dapat dilihat pada tabel 4.3:

Tabel 3 Uji Statistik (Analisis Post-hoc Bonferroni) Selisih Kematian telur nyamuk Aedes aegypti Antar Kelompok dengan Berbagai Variasi Dosis. 


\begin{tabular}{|c|c|c|c|}
\hline & erlakuan & $\begin{array}{c}\text { Rata- } \\
\text { rata beda } \\
\text { (butir) }\end{array}$ & p Value \\
\hline \multirow[t]{4}{*}{ Kontrol } & $\begin{array}{c}\text { Konsentrasi } 10 \\
\mathrm{mg} / \mathrm{l}\end{array}$ & $-12,200^{*}$ & ,000 \\
\hline & $\begin{array}{c}\text { Konsentrasi } 13 \\
\mathrm{mg} / \mathrm{l}\end{array}$ & $-14,000^{*}$ & ,000 \\
\hline & $\begin{array}{c}\text { Konsentrasi } 16 \\
\mathrm{mg} / \mathrm{l}\end{array}$ & $-16,000^{*}$ &, 000 \\
\hline & $\begin{array}{c}\text { Konsentrasi } 18 \\
\mathrm{mg} / \mathrm{l}\end{array}$ & $-18,200^{*}$ & ,000 \\
\hline \multirow{4}{*}{$\begin{array}{l}\text { Konsentra } \\
\text { si } 10 \mathrm{mg} / \mathrm{l}\end{array}$} & kontrol & $12,200^{*}$ & ,000 \\
\hline & $\begin{array}{c}\text { Konsentrasi } 13 \\
\mathrm{mg} / \mathrm{l}\end{array}$ & -1.800 & ,308 \\
\hline & $\begin{array}{c}\text { Konsentrasi } 16 \\
\mathrm{mg} / \mathrm{l}\end{array}$ & $-3,800^{*}$ & ,001 \\
\hline & $\begin{array}{c}\text { Konsentrasi } 18 \\
\mathrm{mg} / \mathrm{l}\end{array}$ & $-6,000^{*}$ & ,000 \\
\hline \multirow{4}{*}{$\begin{array}{l}\text { Konsentra } \\
\text { si } 13 \mathrm{mg} / \mathrm{l}\end{array}$} & kontrol & $14.000^{*}$ & ,000 \\
\hline & $\begin{array}{c}\text { Konsentrasi } 10 \\
\mathrm{mg} / \mathrm{l}\end{array}$ & 1,800 & ,308 \\
\hline & $\begin{array}{c}\text { Konsentrasi } 16 \\
\mathrm{mg} / \mathrm{l}\end{array}$ & $-2,000$ & , 178 \\
\hline & $\begin{array}{c}\text { Konsentrasi } 18 \\
\mathrm{mg} / \mathrm{l}\end{array}$ & $-4,200^{*}$ &, 000 \\
\hline \multirow{4}{*}{$\begin{array}{l}\text { Konsentra } \\
\text { si } 16 \mathrm{mg} / 1\end{array}$} & kontrol & $16,000^{*}$ &, 000 \\
\hline & $\begin{array}{c}\text { Konsentrasi } 10 \\
\mathrm{mg} / \mathrm{l}\end{array}$ & $3,800^{*}$ & ,001 \\
\hline & $\begin{array}{c}\text { Konsentrasi } 13 \\
\mathrm{mg} / \mathrm{l}\end{array}$ & 2,000 & , 178 \\
\hline & $\begin{array}{c}\text { Konsentrasi } 18 \\
\mathrm{mg} / \mathrm{l}\end{array}$ & $-2,200$ & ,101 \\
\hline \multirow{4}{*}{$\begin{array}{c}\text { Konsentra } \\
\text { si } 18 \mathrm{mg} / 1^{-}\end{array}$} & Kontrol & $18,200^{*}$ & ,000 \\
\hline & $\begin{array}{c}\text { Konsentrasi } 10 \\
\mathrm{mg} / \mathrm{l}\end{array}$ & $6,000^{*}$ & ,000 \\
\hline & $\begin{array}{c}\text { Konsentrasi } 13 \\
\mathrm{mg} / \mathrm{l}\end{array}$ & $4,200^{*}$ & ,000 \\
\hline & $\begin{array}{c}\text { Konsentrasi } 18 \\
\mathrm{mg} / \mathrm{l}\end{array}$ & 2,200 & , 101 \\
\hline
\end{tabular}

Table 3 diketahui selisih rata-rata beda telur nyamuk yang tidak menetas pada konsentrasi klorin $10 \mathrm{mg} / \mathrm{l}$ dengan $16 \mathrm{mg} / \mathrm{l}$ memiliki perbedaan yang signifikan $(, 001)$ dengan rata-rata $3,800^{*}$; konsentrasi klorin 10 $\mathrm{mg} / \mathrm{l}$ dengan $18 \mathrm{mg} / \mathrm{l}$ juga memiliki perbedaan yang signifikan $(, 000)$ dengan rata-rata $6,000^{*}$ sedangkan konsentrasi yang tidak memiliki perbedaan yang signifikan ialah pada konsentrasi klorin $10 \mathrm{mg} / \mathrm{l}$ dengan konsentrasi klorin $13 \mathrm{mg} / \mathrm{l}(, 308)$ dengan rata- rata1,800; konsentrasi $13 \mathrm{mg} / \mathrm{l}$ dengan 16 $\mathrm{mg} / \mathrm{l} \quad(, 178)$ dengan rata-rata 2,000; konsentrasi klorin $16 \mathrm{mg} / 1$ dengan konsentrasi klorin $18 \mathrm{mg} / \mathrm{l}(, 101)$ dengan rata-rata 2,200.

\section{PEMBAHASAN}

\section{Analisis perbedaan konsentrasi klorin terhadap daya tetas telur nyamuk Aedes Aegypti.}

Berdasarkan hasil penelitian yang diperoleh dari uji akhir ,yaitu persentase kematian telurnyamukAedes aegypti yang meningkat dengan semakin tingginya konsentrasi klorin menunjukkan adanya efek toksik dari klorin terhadap telur nyamuk Aedes aegypti. Pada kontrol negatif $(0 \mathrm{ml})$ terdapat telurnyamuk yang menetas sebanyak 7\%. Apabila persentase telur nyamuk yang menetas diatas $10 \%$, maka penelitian harus diulangi.

Pada penelitian ini juga dilakukan pemeriksa anph dan sisaklor yang dapat dilihat pada tabel 4.1 menunjukkan bahwa php ada kontrolialah 7,47 dan setelah adanya perlakuan $\mathrm{Ph}$ semakin meningkat hingga 7, 82 sedangkan sisa klor pada larutan klorin terendah ialah 26 dan tertinggi 37.

\section{Analisis konsentrasiklorinyang paling efektiv terhadap daya tetas telur nyamuk Aedes Aegypti.}

Peningkatan rata-rata kematian telur nyamuk Aedes aegypti terjadi seiring dengan peningkatan konsentrasi klorin yaitu semakin tinggi konsentrasi maka semakin tinggi pula rata-rata kematian telur nyamuk Aedes aegypti dengan konsentrasi yang paling efektif adalah $18 \mathrm{mg} / \mathrm{l}$, yang bisa di lihat dari hasil uji One Way Anova (table 4.2)

Sifat kimia klorin sangat ditentukan oleh konfigurasi electron pada kulit terluarnya. Keadaan ini membuatnya tidak stabil dan sangat reaktif. Hal ini disebabkan karena strukturnya belum mempuyai 8 elektron (octet) untuk mendapatkan struktur electron gas mulia. Disamping itu, klorin juga 
bersifat oksidator. Seperti halnya oksigen, klorin juga membantu reaksi pembakaran dengan mengahsilkan panas dan cahaya. Hal inilah yang menyebabkan klorin dapat menghambat daya tetas telur nyamuk Aedesaegypti

\section{KESIMPULAN}

1. Konsentrasi klorin dapat menghambat daya tetas telur nyamuk Aedes Aegypti. Konsentrasi klorin $10 \mathrm{mg} / 1$ sebanyak 67 $\%$, konsentrasi klorin $13 \mathrm{mg} / \mathrm{l}$ sebanyak $77 \%$, konsentrasi klorin $16 \mathrm{mg} / \mathrm{l}$ sebanyak $87 \%$, dan konsentrasi klorin $18 \mathrm{mg} / \mathrm{l}$ sebanyak $98 \%$.

2. Semakin tinggi konsentrasi klori nsemakin efektiv sebagai penghambat daya tetas telur nyamuk Aedes Aegypti. Konsentrasi klorin $18 \mathrm{mg} / \mathrm{l}$ adalah dosis yang paling efektiv dalam menghambat daya tetas telur nyamuk Aedes aegypti dengan persentase kematian $98 \%$.

\section{SARAN}

Berdasarkan hasil penelitian yang telah dilakukan dapat diberikan saran sebagai berikut:

1. Bidang Akademik Pendidikan

Diharapkan penelitian ini bermanfaat bagi bidang akademik pendidik yaitu dapat menambah ilmu pengetahuan kesehatan lingkungan khususnya penyakit demam berdarah dengue (DBD).

2. Manfaat Bagi Peneliti Lain

Diharapkan penelitian ini dapat memberikan informasi mengenai metodepengendalianvektorsecaramandirid ansederhana, sehingga diharapkan dapat melanjutkan penelitian ini.

3. Bagi Masyarakat

Diharapkan penelitian ini dapat memberikan informasi bagi masyarakat tentang salah satu solusi pencegahan penyakit demam berdarah dengue (DBD) dengan menggunakan konsentrasi klorin yang mampu menghambat daya tetas telur nyamuk Aedes aegypti.

\section{DAFTAR PUSTAKA}

Bina Ikawati dan Reza Ayu Rizqi Meilani (2015) Pengaruh Konsentrasi Kaporit terhadap daya tetas telur nyamuk Aedes aegypti. Fakultas kesehatan Masyarakat Universitas Diponogero Semarang, Tembalang

Effendy H. Pemberian kalsium hipoklorit dalam air untuk menghambat penetasan telur Aedes sp.[tesis] Fakultas Kedokteran Universitas Muhammadiyah Malang. 2008.

Trpis,dkk 1971, Aedes aegypti and Aedes simponi Breeding in Coral Rock Holes on The Coast of Tanzania. Switzerland

Widoyono.2008. Penyakit Tropis Epidemiologi, Penularan, Pencegahan Dan Pembrantasannya. Jakarta: Erlangga.

Yuliana Rohan Bria, Widiarti, Eko Hartini. (2010). Pengaruh Konsentrasi Tawas Pada Air Sumur Terhadap Daya Tetas Telur Nyamuk Aedes aegypti Di Laboratorium. Universitas Dian Nuswantoro Semarang. 